\title{
The Emotional Intelligence and Success of Women Entrepreneurs in the Beauty Salon Industry in Sri Lanka: A study of Colombo District.
}

R. Senathiraja ${ }^{1}$, Sarath Buddhadasa ${ }^{2}$ and Anushka.Gunasekera ${ }^{3}$

${ }^{1}$ Faculty of Management \& Finance, University of Colombo

${ }^{2}$ Visiting Academy, IHE Imperial Institute of Higher Education

${ }^{3}$ Graduate Student, IHE Imperial Institute of Higher Education

\begin{abstract}
It was observed that a higher percentage of women lead enterprises in hair and beauty salon industry in Sri Lanka. Though this industry is growing at a remarkable rate within the last few years, very few studies focused on the link of Emotional Intelligent (EI) to the success of women enterprises. The purpose of the study is to understand the level EI and its relationship to the Enterprise success of women in the hair and beauty salon industry. It also evaluates how managerial skill, sociocultural context, education age and location play on the success of women enterprises in the industry. The deductive method was adopted, and a sample of 100 women entrepreneurs surveyed by using a structured questionnaire. The findings confirm that there is a higher level of EI in women entrepreneurs lead to the success of their business. At the same time, age and business location and socio-cultural context have a significant impact on their achievements. The study suggested using much of self-management, social awareness and relationship management to develop women into next pedestal of entrepreneurship and also it insists government authorities work toward the country's economic development through focusing in introducing educational programs to improve emotional intelligence in women, during the general education as well as in professional learning.
\end{abstract}


Keywords: Emotional Intelligence (EI), Success of women enterprise, Hair and beauty salon industry, self-management, social awareness, and relationship management.

\section{Introduction}

Throughout many years it is evident that entrepreneurs build the economy of the world. It is evident that, less contribution of women in enterprises compare to men, hence the World Bank recognized the importance of improving the number of women in entrepreneurship. They believed that it might be a fundamental solution to escape from poverty (Devan, 2012). In Sri Lanka, many women do not contribute to socio-economic development because they were majorly trapped into under-valued employment and given fewer opportunities for training and advancement (Herath, 2015). According to census and statistics, $52 \%$ of the Sri Lankan population is represented by women and in Colombo, it is closer to $51 \%$ (Census \& Statistics, 2018). It indicates that women in Sri Lanka could contribute to Sri Lankan economic growth as par as men contribute to it.

Researchers have identified that despite the growth of the number of new ventures by women entrepreneurs seen, there are several challenges women faced compared to men (Arasti, 2011). Recent research findings elaborated that entrepreneurial failures are occurring due to both the internal and external factors and it found that mainly due to financial skills, relationships with partners, and lack of crucial information are playing the vital role in failure in businesses (Atsan, 2016).

In research on earlier era by (Cross and Travaglione, 1993) in entrepreneurship, analyzed that, all the entrepreneurs can read the 
emotions of others around the business and usage of appropriate methods in interacting on those immediately. They stated that women Entrepreneurs require a high level of emotional management and understanding of emotions. According to (Golman, 2011) women show a higher level of empathy and understanding inner emotions, and men show a higher level of ability in managing emotions in crucial situations. (Deshwal, 2016) also discussed how EI impact on organizational performance. The emotional strengths like empathy and social responsibility of women are well encouraged in today's business context. Another study (Boren, 2010) also suggests that an entrepreneur's capability to understand and accomplish their emotional intelligence to maintain successful emerging ventures. After years of the research, a substantial rate of new venture failure is still evident. Furthermore, it understood that without proper management of emotions by women had led several venture failures.

(Ngah \& Salleh, 2015) stated that entrepreneurs with higher Emotional Intelligent were able to do better negotiations, build customer relationships and demonstrate excellent leadership and also highlighted Emotional Intelligent leads to enable creativity and innovation to cater opportunities around them. The ability of innovative leadership may enhance the motivation of employees to deliver better outputs.

In Sri Lanka, Dissanayaka 2010) explained that managers in the Banking Industry exhibit a significantly higher level of emotional competencies, and it guides managers to understand and manage their emotions and relationships. Finally, it links to the success of the organization. 
Although, it is proven empirically that emotional Intelligent serves as a driver of favorable outcomes for entrepreneurs (Nhah \& Salleh, 2015); (Boren, 2010); (Goldman, 1995) lack of studies on emotional Intelligent, entrepreneurial perspectives. In Sri Lanka to become successful, women entrepreneurs have utilized better psychological characteristics, experience, and knowledge of early childhood in business, competencies of an entrepreneur, education, and learning, external support, and the culture. According to researchers (Ranasinghe, 2008; Ifthikar \& Senathiraja, 2014) also proved that factors such as early childhood experiences, psychological characteristics, family support, social networks, and socio-cultural values had a significant influence on women entrepreneurs venturing activities in Sri Lanka. The findings reveal the entrepreneurial characteristics of Muslim women to be; proactive, selfmotivated, opportunistic, creative, self-confident, internal locus of control, need for achievement and innovation in the Sri Lankan context.

Among the most of negative observation of women and entrepreneurship, it was seen a higher percentage of women lead enterprises in hair and beauty salon industry in a local context (Premathilaka, 2018). Even though the global hair and beauty salon industry refers to both the beauty services and retail of beauty products. In Sri Lanka it is mostly considered the smaller scale independent hair and beauty salons as the main part of the industry. The industry primarily consists of 3 segments, such as hair dressing, beauty and bridal dressing. Beauty segment offers services like skin care treatments (facials), eyebrow/eyelash, manicures, pedicures, makeup application, massages, waxing and other non-medical beauty treatments. On the other hand, hairdressing segment offer services such as cutting, coloring, styling, shampooing, permanents, tanning and non- 
medical hair restoration techniques. This industry was chosen due to the higher percentage of ventures owned by women, the measures of dependent variables in each venture will show an autonomy, the consistency of variables to a greater extent, high number of ventures and ability of higher rate of participation, and due to easy access with prior appointments.

It was understood that, the amount of research done in this industry, to understand EI and its link to the success of enterprises by women was minute. Therefore, this study also insists on the need of identifying "what are the influential factors and the role of EI of the success of women lead enterprises in hair and beauty salon industry in Sri Lanka.?"

The Objectives are to:

- Understand the level of Emotional Intelligent and the level of success of enterprises of women entrepreneurs in the hair and beauty salon industry in Sri Lanka.

- Examine the relationship between the Emotional Intelligence and Enterprise success of women in the hair and beauty salon industry.

- Evaluate the impact of moderating factors (managerial skill, sociocultural context, an education age, and location) on the connection between Emotional Intelligence and the success of the enterprise of women in hair and beauty salon industry.

Only a handful of research conducted on successful women entrepreneurs in Sri Lanka (Amarasiri, 2002; Ranasinghe 2008; Ifthikar \& Senathiraja 2014). The discussion concludes the need of studying "what is the role of emotional intelligence in the enterprise success of women entrepreneurs?" 


\section{Literature Review}

\section{Hair and beauty salon industry}

Among the most of negative observation in women and entrepreneurship, it was seen a higher percentage of women lead enterprises in hair and beauty salon industry in a local context (Premathilaka, 2018). Hence the scope of research was driven to limit the scope of research to women entrepreneurs in the hair and beauty salon industry related to Colombo district. Hair and beauty salon industry of the country is growing at a remarkable industry in Sri Lanka. The context refers to contribute to the high demand for beauticians in the country (Fernando, 2011).

\section{Women Entrepreneurs}

Women who play an intriguing role by frequently interacting and actively adjusting herself with socio-economic, financial and support spheres in society is called women entrepreneur (Pareek, 1992). (Tambunan, 2009) divided women entrepreneurs into three categories of chance, forced and created.

\section{Emotional Intelligence and Theories}

Emotional Intelligence is the skill of recognizing the meanings of emotions and the relationships, and ability to reasoning and problemsolving by those emotions (Golman 1995). Furthermore, (Bradberry, 2014) describes two main competencies in EI. Those are personal competency, and social competency and these competencies are divided further into awareness and management. 
The emotional strengths like empathy and social responsibility of women are well encouraged in today's business context. Researchers in the Encyclopedia of Applied Psychology guides (2004) noted three appropriate frameworks or models of emotional intelligence: Mayer and Salovey ability framework, Daniel Goleman's mixed framework and BarOn framework. Mayer and Salovey ability framework, three aspects of EI, considered as Emotions: expression and appraisals; Emotional: Regulation and Emotions: Utilization.

Goleman's Mixed Model (1998) stated in his theory that EI understood as a result of both ability and competency. It elaborates the need for studying EI as personality traits and as a social character. It includes five components Self-awareness, Self-regulation, Empathy, Motivation, and Social scale. However, Bar-On Model (1997b, 2000) argued that EI is as a non-cognitive skill of an individual and termed as Emotional, Social Intelligence and the framework consists of five clusters such as Intrapersonal, Inter-personal, Stress Management, Adaptability, and General Mood.

These theories evolved, and Bradberry (2014) introduced four Grid Framework and explained to EI as two main competencies. Those are personal competency, and social competency and these competencies are divided further into awareness and management. Finally, it derived the below four core skills such as Self Awareness, Self-Management, Social Awareness, and Relationship Management. 


\section{Figure 1: Segments of emotional intelligence}

\begin{tabular}{|l|l|l|}
\hline & What I See & What I Do \\
\hline $\begin{array}{l}\text { Personal } \\
\text { Competency }\end{array}$ & Self-Awareness & Self-Management \\
\hline $\begin{array}{l}\text { Social } \\
\text { Competency }\end{array}$ & Social Awareness & $\begin{array}{l}\text { Relationship } \\
\text { management }\end{array}$ \\
\hline
\end{tabular}

Source: (Bradberry, 2014)

\section{Small Enterprise success and other factors}

Due the philosophy of critical realism adapted in this research, it emerged the need of understanding the portrayed view of the context in which EI contribute to enterprise success. Hence the research also contributed to the understanding of the context of impact of other factors like age, business location, education, socio-cultural context and managerial skill on the relationship of EI and enterprise success of women in hair and beauty salon industry.

According to the past researchers, many factors influence on success of SMEs such as entrepreneurial traits (Kristiansen, Furuholt, \& Wahid, 2003; and Rutherford \& Oswald, 2000), qualities of SME (Kristiansen, Furuholt, \& Wahid; 2003), management and learning (Swierczek \& Ha, 2003), products and services, customers and markets (Kirca, et at.,2005), the way of doing business and cooperation, resources and finance (Swierczek \& Ha, 2003; and Kristiansen, Furuholt \& Wahid, 2003). (8) strategy (McMahon, 2001), external environment (Indarti \& Langenberg, 2005); and internet Hesselmann \& Comcare 2002). According to 
Budhadasa (2018) SMEs growth is limited by entrepreneurs' attitude and behavior.

People rarely define terms such as success and failure; when they do, they invite endless complaints. Past research on SME has used a range of variables measure growth but most widely used measures are sales and employment. Employment is a widely used measure of growth (Barringer et al., 2005). However, the researchers have used average income, business tenure and number of employees as criteria to measure the success. With this background drawing the attention to defining SMEs is essential. There is no widely accepted definition of SMEs (Ayyagari et al., 2003; Budhadasa, 2009; Gamini \& Senathiraja, 2003).

\section{Conceptual Model}

It is expected to find -out the correlation between Emotional intelligence (independent variables) and entrepreneurial success (dependent variable) of women in the Colombo district. Moreover, the level contribution of intervening factors on the above relationship.

The success of an entrepreneur will depend on various indicators, such as the entrepreneur's success the term of the successful entrepreneur, and the success of venture (Crane \& Crane, 2007). 
Figure 2: Conceptual model of the study

\begin{tabular}{|c|c|c|}
\hline & Intervening variable factors & \\
\hline & Age & \\
\hline & Managerial skiils & \\
\hline & Business location & \\
\hline & Socio-cultural context & \\
\hline & Education & \\
\hline & & \\
\hline Independent Variables & $\downarrow$ & Dependent variables \\
\hline Emotional intelligance & & Business success \\
\hline Self-awareness & & Buusiness income \\
\hline Self management & & Number of Employees \\
\hline Social Awareness & & Business tenuer \\
\hline Relationship management & & \\
\hline
\end{tabular}

However, entrepreneurial success can define in two different ways according to the previous research data. They are a success through performance and psychological success (Juhdi, 2013). Furthermore, financial success will describe by average income, growth in the aspect of resources and sales, company revenues (Baron \& Markman, 2003). Recent research reveals that a higher percentage of enterprises led by women are with relatively lesser tenure compare to that of men (Mitchelmore, 2013). It understood that to understand the success of the venture, factors like income and revenue, customer satisfaction, tenure, growth in the aspect of increment in resources like number of employees

The study may focus on understanding the average income/revenue of the venture, some employee increment during the tenure, the tenure of the venture. Customers' satisfaction may not measure due to the inability to use planned methods and instrument in the measuring efforts in this sector. 


\section{Entrepreneurship and its link to EI}

It was understood that, individuals with high EI evaluates and obtained relevant information needed for better decision making in a much frequent manner and EI have indirect impact on superior decision making in human entrepreneurial behavior (Fallon, Matthews, Panganiban, Wohleber \& Roberts, 2013). It was found out; Emotional intelligence converts individuals to more efficient business people, hence organizations become more productive, further the study advice appropriate usage of EI in management of businesses is not a fashion but a must (Alnabhan, 2005). Increased level of Emotional intelligence builds the empathy in human behavior and results effective business communicators (Carrillo, 2018). Accordingly, the following hypothesis derived from understanding the level of emotional intelligence of women entrepreneurs.

H1: There is a higher level of emotional intelligence in women entrepreneurs in the hair and beauty salon industry in Sri Lanka.

\section{Emotional intelligence and Enterprise success}

The research on entrepreneurship and EI confirms that, there is a significant relationship in between Level of Self-awareness and entrepreneurial success of individuals (Leutner, \& Chamorro-Premuzic, 2011). In many studies it was understood that, to become successful, entrepreneurs need to have higher levels of Willingness, ability and arrangements in cognitive process (García, 2014). The 'self-awareness' aspect of EI will be explained (Bradberry, 2014) the argument presented above. 
As the description of Schneider there is a direct relationship in between risk taking ability, innovativeness and self- efficacy of women entrepreneurs and business success (Schneider, 2017). The further study suggests that, Core Self-evaluation was significantly related to the total entrepreneurial activity (Ahmetoglu, Leutner, \& Chamorro-Premuzic, 2011). Core self-evaluation is consisting of Neuroticism, and Self-esteem, Self-Efficacy and Locus of Control (Judge \& Bono, 2001). This seems to be appropriately described by the Bradberry as 'Self-management' arm of emotional intelligence (Bradberry, 2014).

According to the study by Baron and Markman it is evident that, when there is higher level of social competence demonstrated by the entrepreneur, there is greater financial success seen in the venture, and this social competence includes perception about society by the entrepreneur, social adaptability of the individual, expressiveness in relationships (Baron \& Markman, 2003). The variable of 'perception of society by the entrepreneur' is a direct component of 'Social awareness' attribute of EQ and other variables can be describing through the 'Relationship management' attribute of EQ (Bradberry, 2014).

In recent studies it was found out that, positive emotional intelligence can improve the level of innovation of the entrepreneur and influence the success of "relationship management through regulation of others emotions" and have shown the major benefits in business success compare to other aspects of EI (Ngah \& Salleh, 2015). Furthermore, in a comparative study, it was understood that, successful entrepreneurs display higher levels of interpersonal relationships compared to unsuccessful entrepreneurs (Karimi, Kloshani \& Bakhshizadeh, 2012). 
The discussion concludes the fact that, there is a relationship between relationship management and outcomes in entrepreneurship.

According to Moore women have less access to social network compared to men, due to the lack of appropriate usage of relationship by the women entrepreneurs. Further research by Ngah and Salleh confirm that, appropriate usage of others' emotion by entrepreneurs has a significant impact on entrepreneurial success (Ngah \& Salleh, 2015). Entrepreneurs with ability of using emotional intelligence over the relationships of others were able to gain advantages in negotiations, attract and sustain customers as well as lead the business, which support to entrepreneurial success (McLaughin, 2012). These conclude that 'Relationship management' attribute (Bradberry, 2014) of EQ has a direct link to entrepreneurial success.

$\mathrm{H} 2$ : There is a significant relationship between EI and success of women Enterprises in hair and beauty salon industry

$\mathrm{H} 2.1$ : There is a significant relationship between Self-awareness and success of women Enterprises in hair and beauty salon industry

$\mathrm{H}$ 2.2: There is a significant relationship between Self-management and success of women Enterprises in hair and beauty salon industry in Sri Lanka

H.2.3: There is a significant relationship between Social awareness and success of women Enterprises in hair and beauty salon industry in Sri Lanka 
$\mathrm{H}$ 2.4: There is a significant relationship between Relationship management and success of women Enterprises in hair and beauty salon industry in Sri Lanka

It observed that emotional intelligence and business success might influence by some other factors. Emotional intelligence per se, will not cover the success of entrepreneur (Cherniss \& Goleman, 2001). Need for appropriate management to build a successful business is a wellestablished understanding. Management factors like financial control, proper record management, high planning skills, and marketing ability may support the success of the enterprise. Research suggests that management skill is as a critical factor to become successful in the enterprise (Kaushik \& Sen, 2013). Even in women lead ventures, success depends on the managerial process and financial performance (Lee, Yang, 2013).

H3: There is a significant impact on the relationship of emotional intelligence and success of women Enterprises by Managerial skills of individuals in the hair and beauty salon industry in Sri Lanka

Factors like background education may enhance the capabilities and skills of an entrepreneur and can understand as factors in learning dimension. The recent study suggests that background education significantly contributes to entrepreneurial success (Alozairi, 2018). At the same time, women entrepreneurs have utilized experience and knowledge of early childhood in business, education and learning, experience and knowledge of early childhood in business (Ranasinghe, 2008; Ifthikar, \& Senathiraja 2014 ). 
Education is one of the characteristics of women entrepreneurs that can affect their business performance, and literature supports that education and managerial experience may contribute to women's business growth but certainly has a positive impact on entrepreneurial performance (Gatewood, 2004). According to Wit and Van (1989), individuals with a high level of education are more likely to engage in entrepreneurship. More specific to women studies done by Muia, j. 1. (2015), women were found to be more mature in terms of age, level of education and equipped with work experience in comparison to non-entrepreneurs.

H4: There is a significant impact on the relationship of emotional intelligence and success of women Enterprises by the educational background of individuals in the hair and beauty salon industry in Sri Lanka

Entrepreneurial culture and role of the family will consider as sociocultural context factors of the entrepreneur. Furthermore, according to Wong (2014) entrepreneurial culture is the way that organizations, society, and government supports or champions entrepreneurship. Even though there is no difference in support of the government in entrepreneurial culture, within the scope of the research, the effect of society may differ to each. Within the same geographic area, there are different social classes. Research has found out there is a significant impact on individuals' cognition and the way of self-views by social class even within the same geographic area (Varnum et al., 2010). Role of the family may affect the entrepreneurial thoughts and personality in venture creation (Ranwala, 2016). 
H5: There is a significant impact on the relationship of emotional intelligence and success of women Enterprises by the socio-cultural context of individuals in the hair and beauty salon industry in Sri Lanka

Micro-environment factors like the location, market acceptance, consumer purchasing power will affect the business outcome of the venture (Lee \& Yang, 2013). It was understood even in Sri Lanka to become the success in business, venture location contributes heavily ( Weerasinghe et al., 2013). Because location affects foot traffic, parking, purchasing abilities and needs of surrounding potential customers, even within the selected geographic area.

H6: There is a significant impact on the relationship of emotional intelligence and success of women Enterprises by Business location in hair and beauty salon industry in Sri Lanka.

\section{Operationalization of variables}

The existing measures were modified to operationalize the study variables. Table 1 presents the operationalization of the study variables. The dimensions of the EI variable are related to Self-Awareness, SelfManagement and Social Awareness. The capability of understanding emotions, willingness to arrange thoughts and ability to arrange thoughts are the indicators of self-awareness. The dimension self -management measured by the indicators of risk-taking ability Innovativeness, selfefficacy, flexible behavior, positive behavior. The indicators of Relationship Management are the ability of regulation of other emotions and ability to manage interactions with others. The indicators of social Awareness dimension are the perception about society/others by the 
entrepreneur, Social adaptability of the individual, and expressiveness in relationships. Moderating variables are consisting of Socio-cultural context, Education, Age, Managerial skills and Business location. Enterprise success measured by the indicators of Average income, Business tenure, and Number of employs. All the dimensions of EI, sociocultural variables and managerial skills were measured using a five-point Likert scale and, points anchored as $1=$ strongly disagree to $5=$ Strongly Agree. All other variables were age, education, managerial skills, and business location and business success measured by MCQs, which ask participants to describe their conditions. 


\section{Table 1: Operationalization of variables}

\begin{tabular}{|l|l|l|}
\hline \multicolumn{1}{|c|}{ Variables } & Dimensions & Literature \\
\hline $\begin{array}{l}\text { Emotional Intelligence } \\
\text { (EI) is the capability of understanding and evaluating } \\
\text { feelings of ownership and other feelings and } \\
\text { understanding the differences between them and } \\
\text { guide their behavior for better outcomes. }\end{array}$ & $\begin{array}{l}\text { Self-Awareness } \\
\text { Self- } \\
\text { Management } \\
\text { Social } \\
\text { Awareness and } \\
\text { Relationship } \\
\text { Management }\end{array}$ & $\begin{array}{l}\text { Bradberry, T. } \\
(2014)\end{array}$ \\
\hline $\begin{array}{l}\text { Socio-cultural context: } \\
\text { Entrepreneurial cultural support; Role of family } \\
\text { context in entrepreneurial learning. }\end{array}$ & $\begin{array}{l}\text { Role of family } \\
\text { in business } \\
\text { leanings, } \\
\text { Entrepreneurial } \\
\text { culture }\end{array}$ & $\begin{array}{l}\text { Wong, } \\
\text { Ranwala, 2016; } \\
\text { Varnum et al., } \\
2010\end{array}$ \\
\hline $\begin{array}{l}\text { Education } \\
\text { It consists of the general and professional education } \\
\text { of the entrepreneur. General education represents } \\
\text { education from childhood up to this stage as a student } \\
\text { in general. Profession education relates to the } \\
\text { education related to hair and beauty salon industry. }\end{array}$ & $\begin{array}{l}\text { Level of general } \\
\text { education, Level } \\
\text { of professional } \\
\text { education }\end{array}$ & $\begin{array}{l}\text { Gatewood, } \\
\text { 2004).; Wit and } \\
\text { Van (1989), }\end{array}$ \\
\hline $\begin{array}{l}\text { Age } \\
\text { The length of the time by years the individual has } \\
\text { spent, at the stage of questionnaire entered }\end{array}$ & $\begin{array}{l}\text { Age of the } \\
\text { entrepreneur at } \\
\text { the beginning of } \\
\text { a venture }\end{array}$ & $\begin{array}{l}\text { Marketing } \\
\text { ability, financial } \\
\text { skill } \\
\text { Planning skills, } \\
\text { Record } \\
\text { (2015 }\end{array}$ \\
\hline $\begin{array}{l}\text { Managerial skills: } \\
\text { The skills are the required competencies by the } \\
\text { entrepreneur in managing the business. }\end{array}$ & $\begin{array}{l}\text { Kaushik, Kakoli } \\
\text { Sen, 2013 }\end{array}$ \\
\hline $\begin{array}{l}\text { The place where the firm operates in comparison to } \\
\text { closest town considered on the center place of } \\
\text { easiness of access by people around the area. }\end{array}$ & $\begin{array}{l}\text { main bus route } \\
\text { Rusiness Location: }\end{array}$ & $\begin{array}{l}\text { Weerasinghe, et } \\
\text { al., 2013 }\end{array}$ \\
\hline
\end{tabular}




\begin{tabular}{|l|l|l|}
\hline Enterprise Success: It defined in terms of average & The Average & (Baron \& \\
income (The average monthly profits taken-out by the & income, & Markman, \\
entrepreneur from the venture), Business tenure & Business tenure, & 2003);(Siwan \\
(Business tenure is the length of time, that venture & and Number of & Mitchelmore, \\
held its existence) and Number of employees & employees & 2013 \\
& & \\
& & \\
\hline
\end{tabular}

\section{Methods}

The researchers followed a positivist research approach. It attempts to establish a relationship between emotional intelligence and Enterprise success of women entrepreneurs in the hair and beauty salon industry in Colombo district. The hypotheses developed through the literature review were tested using a quantitative approach based on the cross-sectional survey design. Through a comprehensive literature review, a structured questionnaire was developed and used as a central tool in collecting primary data. Administration of the questionnaire to the sample as was operationalized as face to face structured interweaves, to motivate the adequate level of participation, to minimise understanding gaps and to maintain the high accuracy levels. Procedural remedies were taken at the designing stage to overcome Common Method Variance (CMV). At the same time, measures were psychologically separated by providing clear instructions and translated into respondents' languages.

The sampling frame is the Women entrepreneurs in hair and beauty salon industry in Colombo district. The district selected due to the demand for beauty salons due to high female labor workforce participation within the district. At the same time, only that have employed at least three people in their enterprise included. Since the sampling frame is not available, the 
researchers use convenience sampling method. The sampling unit is a female entrepreneur in the Colombo District. Nearly 150 questionnaires distributed and 60 were ready to participate in the study.

The collected data used to process SPS (Statistical Package for the Social Sciences). The Correlation and Regression analysis used to present through the tables of the outcomes of the analysis. The descriptive statistic used to summarize and describe the data.

The pilot study conducted, and data were analyzed to confirm the reliability and validity of the instruments used. In the validity test of factor analysis through 'varimax rotation' items, nine questions removed from the questionnaire. Cronbach's alpha is the test used in the research due to its ability to measure the consistency of used scales of Likert in the tool. In the aspect of validity test, to understand the content of items ability to test the concept adequately face validity used at the formation of the tool. At the same time, Kaiser- Meryer- Olkin (KMO) measure was obtained to understand the sampling adequacy in the pilot test (Field, 2013). Concurrent validity and predictive validity is used to confirm the ability of items to measure the different respondents differently, and ability predict they are related outcomes (Sekaran \& Bougie, 2014; Sounders et al., 2011). To measure convergent validity significance of "Bartlett's Test" was used. At closer to ' 0 ' value test confirms the identity relationship matrix (Feild, 2013). 


\section{Results and Discussion}

\section{Reliability and validity}

Reliability was tested using Cronbach's alpha. Table 2 summarizes alpha value of each construct. Accordingly, all the values are above 0.60 indicating high internal consistency (Sekaran \& Bougie, 2014; Sounders et al., 2011). The results of the study (See table 3) confirm the reliability and validity in terms of the suitability of items proposed to measure the variables are adequate (KMO) and measure the convergent validity significance of "Bartlett's Test" was used. At closer to ' 0 ' value test confirms the identity relationship matrix.

Table: 2 Reliability and Validity

\begin{tabular}{|c|c|c|c|c|c|c|c|c|c|}
\hline \multirow[t]{3}{*}{ Variable } & \multirow{2}{*}{\multicolumn{3}{|c|}{$\begin{array}{c}\text { Reliability } \\
\text { Cronbach's alpha }\end{array}$}} & \multicolumn{6}{|c|}{ Validity } \\
\hline & & & & \multicolumn{3}{|c|}{ Bartlett's Test } & \multicolumn{3}{|c|}{ KMO } \\
\hline & Result & Standard & Analysis & Result & Standard & Analysis & Result & Standard & Analysis \\
\hline \multicolumn{10}{|l|}{ Independent } \\
\hline $\begin{array}{l}\text { Self- } \\
\text { Awareness }\end{array}$ & 0.64903 & $>0.6$ & Reliable & .000 & $<0.05$ & Valid & 0.5624 & $>0.5$ & Valid \\
\hline $\begin{array}{l}\text { Self- } \\
\text { Management }\end{array}$ & 0.75716 & $>0.6$ & Reliable & .000 & $<0.05$ & Valid & 0.6439 & $>0.5$ & Valid \\
\hline $\begin{array}{l}\text { Social } \\
\text { Awareness }\end{array}$ & 0.87852 & $>0.6$ & Reliable & .000 & $<0.05$ & Valid & 0.6683 & $>0.5$ & Valid \\
\hline $\begin{array}{l}\text { Relationship } \\
\text { Management }\end{array}$ & 0.87286 & $>0.6$ & Reliable & .000 & $<0.05$ & Valid & 0.5038 & $>0.5$ & Valid \\
\hline \multicolumn{10}{|l|}{ Intervening } \\
\hline $\begin{array}{l}\text { Socio- } \\
\text { cultural } \\
\text { context }\end{array}$ & 0.83763 & $>0.6$ & Reliable & .000 & $<0.05$ & Valid & 0.7616 & $>0.5$ & Valid \\
\hline $\begin{array}{l}\text { Managerial } \\
\text { skills }\end{array}$ & 0.82586 & $>0.6$ & Reliable & .000 & $<0.05$ & Valid & 0.774 & $>0.5$ & Valid \\
\hline \multicolumn{10}{|l|}{ Dependent } \\
\hline $\begin{array}{l}\text { Business } \\
\text { Success }\end{array}$ & 0.73582 & $>0.6$ & Reliable & .000 & $<0.05$ & Valid & 0.5872 & $>0.5$ & Valid \\
\hline
\end{tabular}


In research, it is essential to understand the significance of data which is to be presented and to be analyzed. Before descriptive analysis, it confirmed that the variables described in the descriptive analysis are statistically significant through sample Test table presented below. Hence all the variables can be considered as different items to each other (Norusis, 2006), which have measured different aspects of the population.

\section{Descriptive Analysis}

\section{Table 3: One-Sample t-Test Descriptive Analysis}

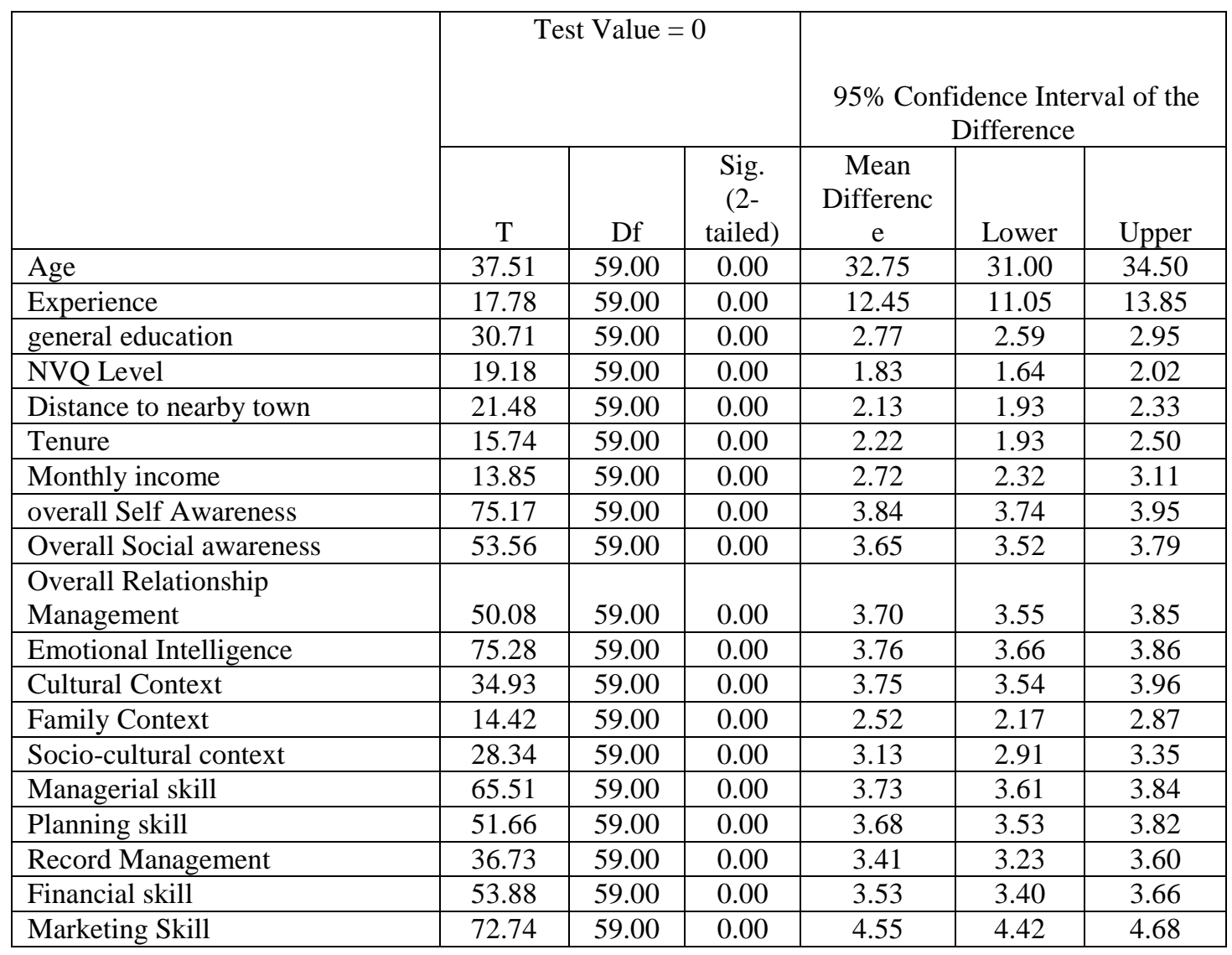


Most of the respondents in the survey are almost middle-aged people with a mean age of 33 years (middle-level age group), and very few represent upper age limit at 55 years and the lower limit at 25 years. Married proportion represents almost two-thirds (65\%) of the total respondents, and it matches with the profile of the average middle-aged population as well. The majority ethnic group in Colombo, $70 \%$ of respondents represented by ethnic-group of Sinhalese, 23.3\% represented by Tamil and $6.7 \%$ represented by Burger population and the ethnicity percentages of the sample was closely associated with that of Colombo district except for the ethnic group. Analysis of general education reveals the fact that most of the respondents (73.3\%) had at least educated up to Advance Level in their school. Only $26 \%$ population was below the standard of the Advance level. The description on firm the fact that most of the individuals had highly experienced and very few embody the lower limit of 5 years of experience among women entrepreneurs in the hair and beauty salon industry. It also observed that up to $83.3 \%$ of the respondents had obtained professional qualification on or below NVQ level 2, which is a comparatively lower level of professional qualification in 6 levels of NVQ in hair and beauty salon industry.

Further, it noted that closer to $2 / 3$ of the respondents' enterprises are located within or immediately outside of the town and it represents $63.3 \%$. Meantime $75 \%$ of the enterprises were operated by 3 to 5 employees in the hair and beauty salon industry. More than 13 employees operate only $3.3 \%$ of salons. Due to the sample framework chosen, enterprises of women in hair and beauty salon industry, below three years of tenure did not consider in the analysis. The description endorses the fact that most the women own enterprises are falling in between 3-8 years in tenure, and 
very few or no enterprises beyond the tenure of 15 years in the hair and beauty salon industry.

It also observed that in the hair and beauty salon industry most of women entrepreneurs have a monthly income level of 60,000-85000 rupees from their enterprise (31.7\%). One fourth (25\%) of women entrepreneurs earn a monthly income of more than Rs 1, 35,000 rupees from their enterprises. The description approves the fact that most of the women own enterprises are encouraged by the immediate society's support and influence than knowledge and skill transferred from the entrepreneur's family to entrepreneur in the aspect of entrepreneurship in hair and beauty salon industry.

The description confirms the fact that women entrepreneurs have a higher managerial skill level. Notably, women have shown the highest level of marketing skill and compare to the lowest skill of record management. However, in overall all the dimensions (marketing skill, Planning skill, financial skill, and record management) women entrepreneurs showed the high average in managing the enterprise in hair and beauty salon industry the results of correlations and hypotheses tastings are given in the following table 4,5 and 6. 
Table 4: Results of Correlation among the variables

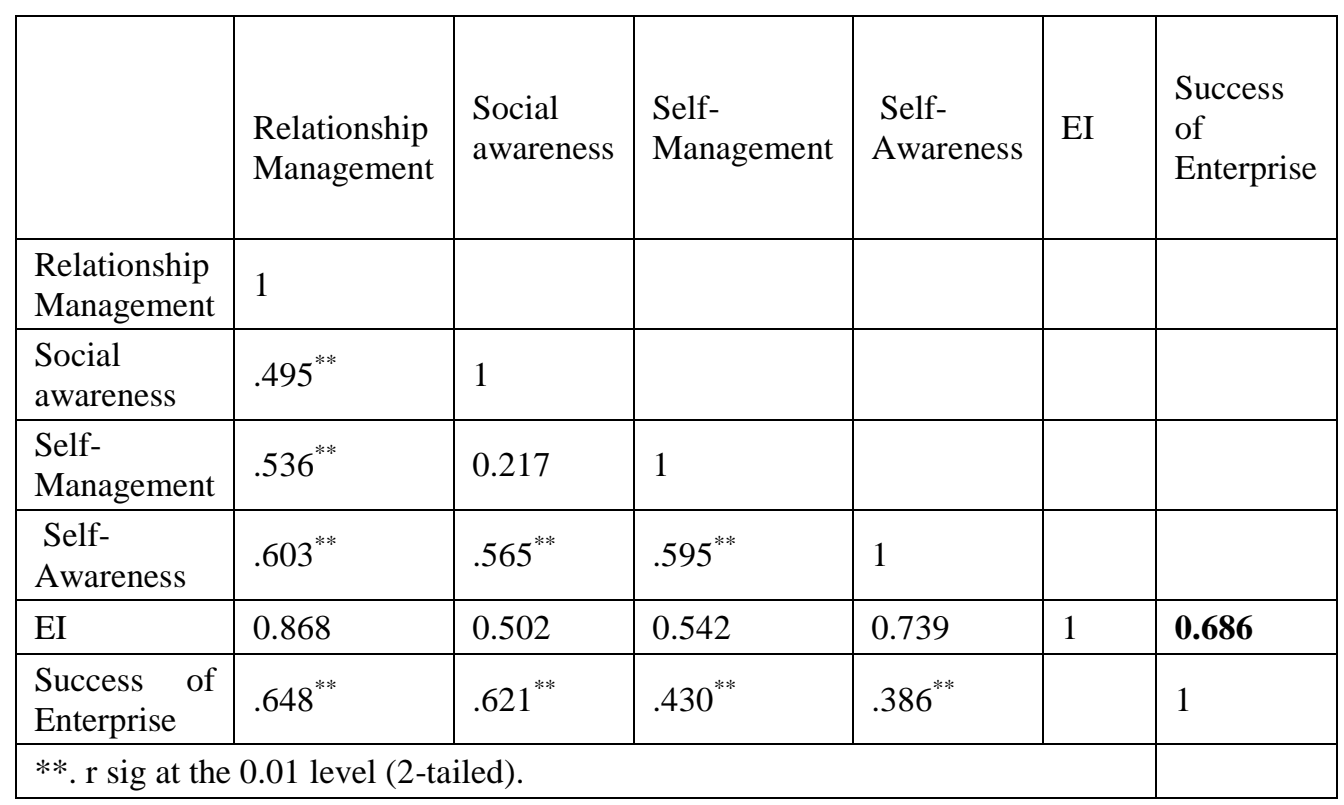




\section{Table 5: Results of the Hypotheses Testing}

\begin{tabular}{|c|c|c|c|}
\hline Hypotheses & Beta & $\begin{array}{c}\mathbf{P} \\
\text { Value }\end{array}$ & $\begin{array}{c}\text { Result on } \\
\text { Hypotheses }\end{array}$ \\
\hline $\begin{array}{l}\text { H1: There is a higher level of emotional intelligence in } \\
\text { women entrepreneurs in the hair and beauty salon } \\
\text { industry in SriLanka. }\end{array}$ & 3.76 & 0.05 & $\begin{array}{l}\text { Supported by } \\
95 \% \\
\text { Confidence } \\
\text { level }\end{array}$ \\
\hline $\begin{array}{l}\text { H2: The Emotional intelligence of women } \\
\text { entrepreneurs in the hair and beauty salon industry in } \\
\text { Sri Lanka positively influence the success of } \\
\text { Enterprises }\end{array}$ & 0.679 & 0.000 & Supported \\
\hline $\begin{array}{l}\text { H2.1: There is a significant relationship between Self- } \\
\text { awareness and success of women Enterprises in hair } \\
\text { and beauty salon industry }\end{array}$ & 0.358 & 0.008 & Supported \\
\hline $\begin{array}{l}\text { H2.2: There is a significant relationship between Self- } \\
\text { management and success of women Enterprises in hair } \\
\text { and beauty salon industry in Sri Lanka }\end{array}$ & 0.29 & 0.013 & Supported \\
\hline $\begin{array}{l}\text { H.2.3: There is a significant relationship between } \\
\text { Social awareness and success of women Enterprises in } \\
\text { hair and beauty salon industry in Sri Lanka. }\end{array}$ & 0.543 & 0.000 & Supported \\
\hline $\begin{array}{l}\text { H2.4: There is a significant relationship between } \\
\text { Relationship-management and success of women } \\
\text { Enterprises in hair and beauty salon industry in Sri } \\
\text { Lanka }\end{array}$ & 0.44 & 0.000 & Supported \\
\hline $\begin{array}{l}\text { H3: There is a significant impact on the relationship of } \\
\text { emotional intelligence and success of women } \\
\text { Enterprises by Managerial skills of individuals in the } \\
\text { hair and beauty salon industry in Sri Lanka. }\end{array}$ & 0.2 & 0.100 & $\begin{array}{l}\text { Not } \\
\text { Supported }\end{array}$ \\
\hline $\begin{array}{l}\text { H4: The relationship between the Emotional } \\
\text { Intelligence and Enterprise Success of women } \\
\text { entrepreneurs influenced by their educational } \\
\text { background in the beauty salon industry in Sri Lanka }\end{array}$ & -0.12 & 0.362 & $\begin{array}{l}\text { Not } \\
\text { Supported }\end{array}$ \\
\hline $\begin{array}{l}\text { H5: The relationship between the Emotional } \\
\text { Intelligence and Enterprise Success of women }\end{array}$ & - & 0.240 & Not \\
\hline
\end{tabular}




\begin{tabular}{|l|l|l|l|}
\hline $\begin{array}{l}\text { entrepreneurs influenced by their socio-cultural context } \\
\text { in the beauty salon industry in Sri Lanka. }\end{array}$ & 0.154 & & Supported \\
\hline $\begin{array}{l}\text { H6: Business Location influences the relationship } \\
\text { between the Emotional Intelligence and Enterprise } \\
\text { Success of women entrepreneurs in the beauty salon } \\
\text { industry in Sri Lanka. }\end{array}$ & 0.211 & 0.000 & Supported \\
\hline $\begin{array}{l}\text { H7: Age influences the relationship between the } \\
\text { Emotional Intelligence and Enterprise Success of } \\
\text { women entrepreneurs in the beauty salon industry in } \\
\text { Sri Lanka }\end{array}$ & 0.221 & 0.020 & Supported \\
\hline
\end{tabular}

Note: ${ }^{* * P} \leq \mathbf{0 . 0 5}$

Table 6: Results of Moderating impact

\begin{tabular}{|c|c|c|c|c|c|c|}
\hline \multirow[b]{2}{*}{ Hypotheses } & \multirow[b]{2}{*}{ Beta } & \multirow[b]{2}{*}{$\mathbf{P}$} & \multicolumn{4}{|c|}{ Under the Barron and Kenny method } \\
\hline & & & & Beta & $\mathbf{P}$ & $\begin{array}{l}\text { Result on } \\
\text { Hypotheses }\end{array}$ \\
\hline \multirow{3}{*}{$\begin{array}{l}\text { H6: Business Location influences } \\
\text { the relationship between the } \\
\text { Emotional Intelligence and } \\
\text { Enterprise Success of women } \\
\text { entrepreneurs in the beauty salon } \\
\text { industry in Sri Lanka }\end{array}$} & -0.211 & 0.00 & EI & 0.585 & 0.00 & \multirow[t]{3}{*}{ Supported } \\
\hline & & & & & & \\
\hline & & & $\begin{array}{l}\text { Business } \\
\text { location }\end{array}$ & 0.211 & 0.049 & \\
\hline \multirow{2}{*}{$\begin{array}{l}\text { H7: Age influences the relationship } \\
\text { between the Emotional Intelligence } \\
\text { and Enterprise Success of women } \\
\text { entrepreneurs in the beauty salon } \\
\text { industry in Sri Lanka }\end{array}$} & 0.221 & 0.02 & EI & 0.651 & 0.00 & \multirow[t]{2}{*}{ Supported } \\
\hline & & & Age & 0.221 & 0.022 & \\
\hline
\end{tabular}

Note: ${ }^{* * P} \leq \mathbf{0 . 0 5}$ 
As per the results of hypothesis testing, the impact on emotional Intelligence on Enterprise success of women Entrepreneurs is at 95 percent confidence level in overall levels of EI and the dimensions of Emotional intelligence. Age of the women entrepreneurs and business location recognized as a moderating factor on the relationship between emotional intelligence and enterprise success. However, three hypotheses rejected. Accordingly, it can conclude that there is no significant impact on the relationship of emotional intelligence and success of women Enterprises by managerial skill, Sociocultural context and educational level of the women entrepreneurs in hair and beauty salon industry in Sri Lanka.

\section{Discussion}

The theory of success of the small business provided many arguments for the groundwork for the impact of several factors including emotional intelligence of the leaders of the organizations. A finding of this study was that EI was the primary predictor of enterprise success in the small sector, but the combination of EI and personality served as a stronger predictor of business and entrepreneur 's success. The higher level of success corresponded to greater levels of EI. The findings confirm the fact that there is a higher level of emotional intelligence in women entrepreneurs in the hair and beauty salon industry. The implication is that soft skills like EI and specific characteristics may be closely related to women entrepreneurs' business success in the hair beauty salon industry in Sri Lanka. Conceptually, our results are previous descriptions of emotionally intelligent individuals (Albritton, 2003; Holcomb et al., 2004; Cross \& Travaglione, 1993). 
The obtained evidence suggests that the connection between the Emotional intelligence and success of women Enterprises in hair and beauty salon industry in Sri Lanka. The results align with the previous findings of Boren (2010). At the same time, the Majority of the women entrepreneurs in this salon industry has a high level of Self-awareness, Self-management Social awareness and Relationship-management are positively influenced on their enterprise success (García, 2014); (Gorkan, Franziska \& Chamorro-Premuzic Tomas, 2011) (Baron \& Markman, 2003); (Karimi at el., 2012). Despite insist of literature about the positive influence of self-awareness to the success of entrepreneurs (García, 2014), in the dimensional analysis of EI, confirmed that there is a significant negative relationship between Self-awareness and success of women Enterprises in hair and beauty salon industry. It reveals that when women show a higher level of self -awareness the enterprise success may lower due to the negligence in understanding negative emotions and over consideration of positive emotions.

However, the findings not supported impact on the relationship of emotional intelligence and success of women Enterprises by sociocultural context, managerial Kills, and educational level of the entrepreneurs in hair and beauty salon industry in Sri Lanka. Nevertheless, the findings not attributed to most of the entrepreneur's success determined by the educational level, social context and managerial skills hence challenge the findings of previous research (Ranwala, 2016; Alozairi, 2018). However, this is an area that should be discussed further by another researcher in the broader spectrum.

The research findings suggest that the emotional intelligence has a significant impact on the success of women Enterprises by the age of the 
individual in hair and beauty salon industry, hence confirm the findings of previous research (Alozairi, 2018). Moreover, also evidence suggests that there is a significant impact on the relationship of emotional intelligence and success of women Enterprises by a Business location of the enterprise in hair and beauty salon industry, hence confirm the findings of previous research (Weerasinghe, Batagoda, \& Jayasundara, 2013). Based on the findings the existing knowledge claiming that $\mathrm{EI}$ is directly influencing on successes of women entrepreneurs in the hair, beauty salon industry in Sri Lanka, meantime the middle age of women and their selection of business location also playing a vital role to make a healthy relationship between the emotional intelligence and enterprise success.

\section{Conclusion, Implications and Further Studies}

Even in different industries like hair and beauty salon industry, the success of women entrepreneurs positively influenced by emotional intelligence. On the other hand, Socio-cultural context, level of managerial skill, general education and NVQ level of professional education cannot impact the relationship of EI to the success of the enterprise in women entrepreneurs in the industry selected. However, women entrepreneurs' age positively affects the outcomes of the relationship of emotional intelligence to success Enterprises due to the ability of age to accommodate the skill and knowledge development in every aspect (Alozairi, 2018). At the same time when the distance to an enterprise from town (Business location) increases the outcomes of a relationship between emotional intelligence and enterprise success. Therefore, it can conclude that when entrepreneurs' emotional intelligence level is high, it will positively influence the enterprise success. It noted that many other factors like managerial skill development, education 
level, age, location, and socio context require further investigation with the broader area of sampling and to see why there is a different finding in the existing knowledge related to the Sri Lankan business framework.

The study conveys an innovative conceptual framework which was developed based on the determinant of the business successes. The study validates different factors, especially selected emotional intelligence on the business success of women in a small industry in a developing country. It also illustrates some of the intervening variables which could work for the women in the selected industry. This study modifies the scale to measure the success of women enterprise in this industry. The study checks the reliability and validity of the measures. Therefore, future researchers can use the same measure.

The main practical implication of the study is the women, who are willing to enter entrepreneurship, need to keep much focus on the characteristic of EI of them, before entering to the field of entrepreneurship. At the same time, the individuals who are already in the field of entrepreneurship need to focus on understanding their levels of emotional intelligence through published questionnaires by reputed institutes. Every women entrepreneur needs to understand the level of each dimension of EI displayed by themselves through the mentioned questionnaire and need to use much of self-management, social awareness, and relationship management to develop them into next pedestal of entrepreneurship. At the same time, the usage of self-awareness needs to be focused much into understanding their negative emotions as well, because over awareness of positive emotions may negate the ability to understand negative emotions hence affect the other dimensions of EI. 
Further, the Government authorities toward the country's economic development need to focus on introducing educational programs to improve emotional intelligence in women, during the general education, because it may increase the participation of women in entrepreneurship and will contribute to enhancing the economic growth of the country. At the same time, related authorities in developing unique industries with higher women's contribution need to focus on developing training programs to improve the EI; hence it may enhance the overall turn-over of those industries.

The direct correlation between EI and age was consistent with Goleman (1998) and Bar-On (2006) who reported a positive correlation between EI and age. That is, the older the participants, the higher their emotional intelligence. Age also correlated with the number of online courses taken by participants. Intuitively, this may explain the length of time women had started. It is another finding that needs further study. Our sample demographics were consistent with only women it may apply to the male entrepreneurs as well. Therefore, this study can be further explored in future studies by considering a diversified sample for a different industry. 


\section{References}

Ahmetoglu, G., Leutner, F., \& Chamorro-Premuzic, T. (2011). EQnomics: Understanding the relationship between individual differences in trait emotional intelligence and entrepreneurship. Personality and Individual Differences, 51(8), 1028-1033.

Albritton, K., \& Bleyer, W. A. (2003). The management of cancer in an older adolescent. European Journal of Cancer, 39(18), 2584-2599.

Alnabhan, O. (2005). Emotional Intelligence and Management. Research Paper; Anglia Ruskin University, Essex, United Kingdom, 1-7.

Alozairi, M. A. S.(2018) Success factors behind Entrepreneurship during an economic crisis: A study of Sam Office Furniture in Erbil-Kurdistan. International Journal of Advanced Engineering, Management and Science, 4(4).

Amarasiri. J. (2002). An exploratory study on a group of selected business women in Sri Lanka. Paper presented at the English National Convention on Women's studies, Colombo, Centre for Women's Research.

Arasti, Z. (2011). Gender Differences in the Causes of Business Failure. Journal of Global Entrepreneurship Research, 95-106.

Atsan, N. (2016). Failure Experiences of Entrepreneurs: Causes and Learning. 12th International Strategic Management Conference, ISMC 2016, 28-30 October 2016, Antalya, (pp. 435 - 442). Antalya: Elsevier.

Ayyagari, M., Demirgüç-Kunt, A., \& Beck, T. (2003). Small and medium enterprises across the globe: a new database. The World Bank. 
Bar-On, R. (1997). The Emotional Quotient Inventory (EQ-i): Technical Manuel. Toronto: Multi-Health Systems. Bar-On, R. (2002).

Bar-On, R. (2006). The Bar-On model of emotional-social intelligence (ESI). Psicothema, 18.

Baron, R. A., \& Markman, G. D. (2003). Beyond social capital: The role of entrepreneurs' social competence in their financial success. Journal of business venturing, 18(1), 41-60.

.Baron, R.A., 2008. The role of affect in the entrepreneurial process. Acad. Manage. Rev. (AMR), 33: 328-340.

Barringer, B. R., Jones, F. F., \& Neubaum, D. O. (2005). A quantitative content analysis of the characteristics of rapid-growth firms and their founders. Journal of business venturing, 20(5), 663-687.

Boren, A. E. (2010). "Emotional Intelligence: The secret of successful entrepreneurship?". DigitalCommons@ University of Nebraska, 55-61.

Bradberry, T. (2014). Emotional intelligence-EQ. Retrieved November 23, 2016.

Bradberry, T. (2014, January 09). Leadership. Retrieved April 23, 2018, from Forbes: https://www.forbes.com/sites/travisbradberry/2014/01/09/emotionalintelligence/\#7335226f1 ac0

Buddhadasa, S. (2009). Situational Analysis of youth entrepreneurship development and income generation in Sri Lanka,Sri Lanka Economic Journal, 10(1),84-130. 
Buddhadasa, S. (2018). Attitudes and Behaviour Orientations of Sri Lankan Entrepreneurs: An Empirical Study of SME Perspectives of Business Development Services (BDSs), Samudhtra Books Publishers.

Census \& Statistics. (2018). Estimates on Mid-Year Population 2012 2017 by District and Sex. Retrieved 05 05, 2018, from Census and Statistics of Sri Lanka: census@ statistics.gov.lk

Cherniss, C., \& Goleman, D. (2001). The emotional intelligence workplace. How to select for a measure and improve emotional intelligence in individuals, groups, and organizations San Francisco: Jossey-Bass.

Colombo District. (2018, November 17). Retrieved February 2, 2019, from

Wikipedia:

https://en.wikipedia.org/wiki/Colombo_District\#Administrative_units

Crane, F. G., \& Crane, E. C. (2007). Dispositional optimism and entrepreneurial success. The Psychologist-Manager Journal, 10(1), 13-25.

Cross, B. and A. Travaglione, 2003. The untold story: is the entrepreneur of the 21 st century defined by emotional intelligence? Int. J. Org. Anal., 11: 221-228.

Cross, B., \& Travaglione, A. (1993). The untold story: is the entrepreneur of the 21st century. International Journal of Organizational Analysis, Vol. 11 Iss: 3 pp. 221 - 228. 
Dissanayaka, M. J. (2010). Role of Emotional Intelligence in Organizational Learning: An Empirical Study Based on Banking Sector in Sri Lanka. Kelaniya: University of Kelaniya.

De Wit, G., \& Van Winden, F. A. (1989). An empirical analysis of selfemployment in the Netherlands. Small Business Economics, 1(4), 263272.

Deshwal, P. (2016). Impact of Emotional Intelligence on Organizational Performance. International Journal of Advanced Research in Management and Social Sciences, 5(1), 173-182.

Devan, J. (2012). The International Bank for Reconstruction and Development. Washington, D.C: World Bank.

Fernando, R. (2011, June 23). Hair and beauty industry surges ahead. Retrieved December 18, 2018, from Daily Financial Times: http://www.ft.lk/article/36223/Hair-and-beauty-industry-surges-ahead

Field, A. (2013). Discovering statistics using IBM SPSS statistics. Sage.

Gamini de Alwis, P. W., \& Senathiraja, R. (2003, November). The impact of the socio-cultural background of the entrepreneur on management and business practices of selected small and medium scale businesses in Sri Lanka. In 9th International Conference on Sri Lanka Studies.

García, O., \& Wei, L. (2014). Translanguaging. The Encyclopedia of Applied Linguistics, 1-7.

Gatewood, E. J., Brush, C. G., Carter, N. M., Greene, P. G., \& Hart, M. M. (2004). Women entrepreneurs, growth and implications for the 
classroom. USA: Coleman Foundation whitepaper series for the USA Association for Small Business and Entrepreneurship.

Goleman D. (1998). Working with Emotional Intelligence. New York: Bantam

Goleman, D. (2011, 04 29). Are Women More Emotionally Intelligent Than Men? Retrieved 04 30, 2018, from Psychology Today: https://www.psychologytoday.com/us/blog/the-brain-and-emotionalintelligence/201104/are-women-more-emotionally-intelligent-men

Golman, D. (1995). Emotional Intelligance. New York: Bantan books.

Herath, H. M. (2015). Place of Women in Sri Lankan Society: Measures for Their Empowerment for Development and Good Governance. Sri Lanka: University of Sri Jayewardenepura.

Hesselmann, H., \& Comcare, P. B. (2002). Benchmarking national and regional e-business policies for SMEs, Final Report of the E-Business Policy Group.

Holcomb, B., Bailey, J. M., Crawford, K., \& Ruffin, M. T. (2004). Adults' knowledge and behaviors related to human papillomavirus infection. The Journal of the American Board of Family Practice, 17(1), 26-31.

Ifthikar, F. B., \& Senathiraja, R. (2014). The factors influencing on income-generating activities of women entrepreneurs: the Case study of selected Muslim Women in Colombo District. International Journal of Social Sciences and Entrepreneurship, 1(9), 502-520. 
Indarti, N., \& Langenberg, M. (2005). A study of factors affecting business success among SMEs: Empirical evidence from Indonesia. Asian Social Science, 7(5), 67-86.

Jarillo, J. C. (1988). On strategic networks. Strategic management journal, 9(1), 31-41.

Judge, T. A., \& Bono, J. E. (2001). Relationship of core self-evaluations traits-self-esteem, generalized self-efficacy, a locus of control, and emotional stability — with job satisfaction and job performance: A metaanalysis. Journal of Applied Psychology, 86(1), 80.

Juhdi, N. H., \& Juhdi, N. (2013). Entrepreneurial success from positive psychology view. In 4th International Conference on Business and Economic Research, Bandung, March (pp. 4-5).

Karimi, P., Kloshani, M., \& Bakhshizadeh, A. (2012). A comparative study of emotional intelligence and cognitive between successful and unsuccessful entrepreneurs. Management Science Letters, 2(6), 20712076.

Kirca, A. H., Jayachandran, S., \& Bearden, W. O. (2005). Market orientation: a meta-analytic review and assessment of its antecedents and impact on performance. Journal of marketing, 69(2), 24-41.

Kristiansen, S., Furuholt, B., \& Wahid, F. (2003). Internet cafe entrepreneurs: pioneers in information dissemination in Indonesia. The International Journal of Entrepreneurship and Innovation, 4(4), 251-263. 
Lee, L., \& Yang, C. L. (2013). Key success factors in a female micro entrepreneurship-A study of the catering business. Service Science and Management Research, 2(3), 39-47.

McMahon, R. G. (2001). Growth and performance of manufacturing SMEs: The influence of financial management characteristics. International Small Business Journal, 19(3), 10-28.

Muia, j. 1. (2015). Influence of personal characteristics on the performance of women-owned enterprises in open air markets. The case of Kathiani sub-county, Machakos county (doctoral dissertation, University of Nairobi).

Ngah, R., \& Salleh, Z. (2015). Emotional Intelligence and Entrepreneurs'innovativeness towards Entrepreneurial Success: A Preliminary Study. American Journal of Economics, 285-290.

Norušis, M. J. (2006). SPSS 14.0 guide to data analysis. Upper Saddle River, NJ: Prentice Hall.

Pareek , (1992). 'Entrepreneurial role stress.', Mimeographed Ahmedabad: Indian Institute of Management.

Pradhan, R. K., \& Nath, P. (2012). Perception of entrepreneurial orientation and emotional intelligence: A study on India's future technomanagers. Global Business Review, 13(1), 89-108.

Premaratne, S. (2002). Entrepreneurial networks and small business development: the case of small enterprises in Sri Lanka. Eindhoven: Technische Universiteit. 
Premathilaka, J. (2018, December 29). Management Assistance, District registrar. (A. Gunasekara, Interviewer)

Ranasinghe, S. (2008). Factors contributing to the success of women entrepreneurs in Sri Lanka. $1^{\text {st }}$ research conference organized by the National Centre for Advanced Studies. Colombo: National Centre for Advanced Studies.

Ranwala, R. S. (2016). Family Background, Entrepreneurship Specific Education, Gender and Venture Creation Knowledge: An Empirical Analysis of Sri Lankan Graduates.

Ranwala, S. (2016). Family Background, Entrepreneurship Specific Education and Entrepreneurial Knowledge in Venture Creation. International Journal of Scientific and Research Publications, Volume 6, Issue 9, 495-501.

Rutherford, M. W., \& Oswald, S. L. (2000). Antecedents of small business performance. New England Journal of Entrepreneurship, 3(2), 21.

Saunders, M. N. (2011). Research methods for business students, 5/e. Pearson Education India.

Schneider, K. (2017). Entrepreneurial Competencies of Women Entrepreneurs of Micro and small enterprises. Science Journal of Education, 252-261.

Sekaran, U., \& Bougie, R. (2014). Research methods for business sixth ed. Chichester: John Wiley\&Sons Ltd. 
Swierczek, F. W., \& Ha, T. T. (2003). Entrepreneurial orientation, uncertainty avoidance and firm performance: an analysis of Thai and Vietnamese SMEs. The International Journal of Entrepreneurship and Innovation, 4(1), 46-58.

Tambunan, T. (2009). Women entrepreneurship in Asian developing countries: Their development and main constraints. Journal of Development and Agricultural Economics, 1(2), 027-040.

Thanuja Kaushik, Kakoli Sen. (2013). What Makes an Entrepreneur successful: An Entrepreneur- Employee Perspective. Journal of Business Management and Research, 33-39.

Varnum, M. E., Grossmann, I., Kitayama, S., \& Nisbett, R. E. (2010). The origin of cultural differences in cognition: The social orientation hypothesis. Current directions in psychological science, 19(1), 9-13.

Weerasinghe T.D., Batagoda C.K., Jayasundara W.H.G.. (2013). Key Success Factors of Small Businesses in Sri Lanka. Proceedings of the 2nd International Conference on Management and Economics 2013 (pp. 1-10). Colombo: International Conference on Management and Economics: University of Sri Jayewardenepura.

Wong, M. A. (2014). Entrepreneurial Culture: Developing a Theoretical Construct and its Measurement. 